\title{
KOMPARASI HASIL BELAJAR MATEMATIKA ANTARA MODEL (MMP) DENGAN MODEL PENGAJARAN LANGSUNG SISWA KELAS VII SMP
}

\author{
Andi Trisnowali MS
}

Dosen STKIP Muhammadiyah Bone

Email: anditrisnowali@gmail.com

\begin{abstract}
ABSTRAK
Penelitian ini bertujuan untuk memperoleh informasi ada tidaknya perbedaan hasil belajar matematika siswa dengan model pembelajaran MMP dan Pengajaran Langsung. Penelitian ini adalah penelitian eksperimen yang bersifat komparatif, populasinya adalah siswa kelas VII SMP Negeri 5 Watampone yang berjumlah tiga kelas. Teknik sampling yang digunakan adalah purposive random sampling cluster yaitu terpilih dua kelas yaitu kelas $V \mathrm{VI}_{A}$ dan $\mathrm{VII}_{B}$ sebagai sampel penelitian. Kelas $V I_{A}$ terdiri dari 27 siswa sebagai kelas eksperimen I yaitu dengan model pembelajaran MMP dan kelas VII ${ }_{B}$ terdiri dari 26 siswa sebagai kelas eksperimen II dengan model pengajaran langsung. Hasil analisis deskriptif menunjukkan bahwa hasil belajar matematika siswa yang diajar dengan model pembelajaran MMP mempunyai skor rata-rata 74,37 yang dikategorikan "tinggi" dengan standar deviasi 12.14 dan persentase ketuntasan 88,89\%. Sedangkan hasil belajar dengan model pengajaran langsung mempunyai skor rata-rata 61.81 yang dikategorikan "tinggi" dengan standar deviasi 13.18 dan persentase ketuntasan 61,54 \%. Dari hasil analisis data untuk statistika inferensial diperoleh nilai $\frac{1}{2} p-$ value $<\alpha$ (taraf signifikansi 0,05) yaitu sebesar $0.0005<0,05$ sehingga $H_{0}$ ditolak. Dengan demikian, terdapat perbedaan hasil belajar dari kedua model pembelajaran di atas dalam hal ini diketahui bahwa model pembelajaran MMP lebih baik daripada model pngajaran Langsung.
\end{abstract}

Kata Kunci : Missouri Mathematics Project, Pengajaran Langsung.

\section{PENDAHULUAN}

Sasaran pendidikan terletak pada Proses Belajar Mengajar (PBM) yang melibatkan pendidik dan peserta didik, karena PBM merupakan ujung tombak dari sistem pendidikan. Keberhasilan pendidikan sangat tergantung pada unsur pelaksanaan pendidikan itu sendiri yaitu guru. Guru secara langsung mempengaruhi, membina dan mengembangkan kemampuan siswa agar menjadi manusia cerdas, terampil dan bermodal tinggi. Oleh karena itu, sistem pengajaran yang digunakan oleh guru harus sesuai dengan kebutuhan materi yang diajarkan, guru juga harus mampu mengembangkan keterampilanketerampilan dalam PBM guna meningkatkan mutu dan prestasi belajar siswa.

Salah satu materi pendidikan yang perlu untuk mendapat perhatian yang cukup oleh para peserta didik adalah pelajaran matematika. Matematika merupakan suatu bidang studi yang amat penting dalam kehidupan sehari - hari. Hampir seluruh aktifitas 
kehidupan kita bersinggungan dengan matematika, sehingga perlu penguasaan yang mantap terhadap bidang studi ini. Namun, sungguh ironi ketika kita melihat keadaan di lapangan, sebagian besar peserta didik menganggap bahwa matematika merupakan suatu bidang studi yang cukup sulit. Hal ini timbul karena keabstrakan matematika terkadang sulit untuk dicerna peserta didik.

Menurut Muhibbin Syam (2003), rendahnya prestasi belajar siswa di bidang studi matematika di sekolah disebabkan oleh banyak faktor. Namun secara garis besar dapat dibagi menjadi 2 macam yakni faktor internal dan eksternal. Faktor internal meliputi motivasi, kemampuan, kesiapan belajar, dan lain-lain. Sedangkan faktor eksternal meliputi sarana dan prasarana, kualitas tenaga pengajar, dan lain -lain.

Ada beberapa model dalam pembelajaran matematika, diantaranya model pengajaran langsung, model pembelajaran kelompok dan klasikal, model Missouri Mathematics Project, dan model pembelajaran kooperatif.

Setiap proses pembelajaran harus dipermantap khususnya pelajaran matematika sesuai dengan prinsip psikologi yang dikemukakan oleh Rochman Natawidjaja (1993) bahwa hasil belajar dapat lebih sempurna apabila sering diulang sering dilatih.

Menurut informasi dari salah satu guru matematika di SMP Negeri 5 Watampone bahwa peserta didik SMP Negeri 5 Watampone kadang mengalami kesulitan belajar karena pada saat guru menjelaskan materi, banyak siswa yang berbicara dengan siswa lain. Disamping itu, apabila ditanya oleh guru, mereka lebih banyak diam. Siswa cenderung pasif dalam berpendapat, mengerjakan soal atau tugas dari guru. Apalagi pelajaran matematika dipandang sebagai pelajaran yang sulit, ditambah minat dan daya pikir yang rendah serta pemahaman yang kurang optimal sehingga matematika tidak dapat berjalan dengan lancar. Pelajaran matematika adalah pelajaran yang sulit untuk saya pahami. Mungkin karena begitu banyak rumus yang harus dihafal.

Untuk mengantisipasi kondisi siswa dalam belajar matematika seperti yang diungkapkan di atas, maka diperkirakan model MMP digunakan. Model pembelajaran Missouri Mathematics Project menjadi pilihan karena model ini dirancang untuk meningkatkan kemampuan siswa dalam memahami konsep, menyelesaikan soal, dan memecahkan masalah-masalah matematika hingga pada akhirnya peserta didik mampu mengkonstruksikan jawaban mereka sendiri karena banyaknya pengalaman yang dimiliki peserta didik dalam menyelesaikan soal - soal latihan. Seperti kita ketahui bahwa ketika berbicara tentang matematika maka tidak terlepas dari soal-soal yang harus diselesaikan. 
Selain dari pada itu hal-hal yang menjadi pertimbangan untuk menerapkan model Missouri Mathematics Project karena memiliki beberapa kelebihan diantaranya:

1. Banyaknya materi yang bisa tersampaikan kepada siswa karena tidak terlalu memakan banyak waktu, artinya penggunaan waktu dapat diatur relatif ketat.

2. Banyak latihan sehingga siswa mudah terampil dengan beragam soal.

Model Missouri Mathematics Project adalah model pembelajaran yang sebelumnya pernah diterapkan oleh salah satu mahasiswi Universitas Muhammadiyah Surakarta Yeni Oktavia prodi pendidikan matematika 2010 dengan judul "Pembelajaran Matematika Dengan Model Missouri Mathematics Project (MMP) Untuk Meningkatkan Motivasi Dan Hasil Belajar Siswa”. Dengan jenis penelitiannya adalah PTK (Penelitian Tindakan Kelas). Subyek penerima tindakan adalah siswa kelas VII-A SMP Negeri 2 Colomadu yang berjumlah 39 siswa dan subyek pelaksana tindakan adalah peneliti dan guru matematika kelas VII-A.Hasil penelitian menunjukkan adanya peningkatan motivasi dan hasil belajar matematika siswa. Hal ini dapat dilihat dari banyaknya siswa yang 1) antusias dalam belajar (senang atau bersemangat mengikuti pembelajaran) sebelum tindakan $15,4 \%$ dan setelah tindakan $79,5 \%, 2$ ) memperhatikan penjelasan guru sebelum tindakan $20,5 \%$ dan setelah tindakan $87,2 \%, 3$ ) mengerjakan soal atau tugas dari guru sebelum tindakan $46,2 \%$ dan setelah tindakan $82,1 \%$, 4) memberikan pendapat dan bertanya sebelum tindakan $17,5 \%$ dan setelah tindakan $53,8 \%$. Hasil tes tertulis yang dilakukan sebelum dan sesudah penelitian menunjukkan adanya peningkatan hasil belajar siswa yang mencapai Kriteria Ketuntasan Minimal (KKM) dari ketentuan sekolah yaitu mencapai nilai $\geq 60$, sebelum diadakan tindakan sebesar $25,6 \%$ dan setelah tindakan 79,5\%. Dapat disimpulkan bahwa pembelajaran matematika dengan model Missouri Mathematics Project dapat meningkatkan motivasi dan hasil belajar siswa.

Hal inilah yang melatarbelakangi penulis tertarik untuk mengadakan penelitian mengenai "Komparasi Hasil Belajar Matematika Antara Model Pembelajaran Missouri Mathematics Projetc (MMP) dengan Model Pengajaran Langsung Siswa Kelas VII SMP Negeri 5 Watampone".

Berdasarkan penjelasan diatas, maka penulis mengemukakan pertanyaan penelitian sebagai berikut:

1. Seberapa besar hasil belajar matematika siswa yang diajar dengan model pengajaran langsung di kelas VII SMP Negeri 5 Watampone?

2. Seberapa besar hasil belajar matematika siswa yang diajar dengan model Missouri Mathematics Project di kelas VII SMP Negeri 5 Watampone? 
3. Apakah hasil belajar matematika siswa kelas VII SMP Negeri 5 Watampone yang diajar dengan menerapkan model pembelajaran Missouri Mathematics Project lebih baik dari pada menerapkan model pengajaran langsung?

Matematika sebagai salah satu cabang ilmu yang dikenal oleh masyarakat awan selama ini hanya dianggap sebagai bilangan - bilangan dan operasinya. Sebenarnya matematika tidak seserdahana itu.

Belajar adalah usaha mengubah tingkah laku. Pengertian yang dikemukakan para ahli, diantaranya Slameto (1995:2) mendefinisikan bahwa belajar adalah suatu proses usaha yang dilakukan seseorang untuk memperoleh suatu perubahan tingkah laku yang baru secara keseluruhan, sebagai hasil pengalamannya sendiri dalam interaksi dengan lingkungannya. Selanjutnya Hamalik (2001) mengemukakan bahwa belajar adalah modifikasi atau memperteguh kelakuan melalui pengalaman. Menurut pengertian ini, belajar merupakan suatu proses, suatu kegiatan dan bukan suatu hasil atau tujuan.

Menurut Charlin (1972) dalam mendefinisikan belajar dengan membatasi belajar dengan dua macam rumusan yaitu 1. Belajar adalah perolehan perubahan tingkah laku yang relatif menetap sebagai akibat latihan dan pengalaman. 2. Belajar adalah proses memperoleh respon - respon sebagai akibat adanya latihan khusus. (Syam, 2003)

Menurut Al Krismanto (2003), struktur pengajaran adalah tahapan kegiatan dalam proses pembelajaran, termasuk perincian waktunya. Komponen struktur pengajaran adalah sebagai berikut :

1. Pendahuluan

2. Pengembangan

3. Penerapan

4. Penutup

Model di atas dapat dimodifikasi menjadi berbagai macam model tergantung situasi yang memungkinkan peserta didik sehingga dapat belajar dengan lebih bermakna. Misalnya untuk matematika, cukup sulit bagi peserta didik mempelajari beberapa konsep atau prinsip sekaligus, baru menerapkannya. Lebih baik, bagian demi bagian seperti tampak pada salah satu model struktur pembelajaran yakni model pembelajaran Missouri Mathematics Project.

Missouri Mathematics Project merupakan salah satu model pembelajaran yang terstruktur dimana struktur tersebut dikemas dalam langkah - langkah sebagai berikut: 
1. Review

Guru dan peserta didik meninjau ulang apa yang telah tercakup pada pembelajaran yang lalu. Yang ditinjau adalah PR, mencongak, atau membuat prakiraan.

2. Pengembangan

Guru menyajikan ide baru dan perluasan konsep matematika terdahulu. Peserta didik diberi tahu tujuan pelajaran yang memiliki "antisipasi" tentang sasaran pelajaran. Penjelasan dan diskusi interaktif antar guru - peserta didik harus disajikan termasuk demonstrasi kongkrit yang sifatnya pictorial atau simbolik. Guru merekomendasikan $50 \%$ waktu pelajaran untuk pengembangan. Pengembangan akan lebih bijaksana bila dikombinasikan dengan control latihan untuk meyakinkan bahwa peserta didik mengikuti penyajian materi baru itu.

3. Latihan Terkontrol

Peserta didik diminta merespon satu rangkaian soal sambil guru mengamati jika terjadi miskonsepsi. Pada latihan terkontrol ini respon setiap peserta didik sangat menguntungkan bagi guru dan peserta didik. Pengembangan dan latihan terkontrol dapat saling mengisi dengan total waktu 20 menit. Guru harus memasukkan rincian khusus tanggung jawab kelompok dan ganjaran individu berdasarkan pencapaian materi yang dipelajari. Peserta didik bekerja sendiri atau dalam kelompok belajar kooperatif.

4. Seat work (Kerja Mandiri)

Untuk latihan/perluasan mempelajari konsep yang disajikan pada langkah 2(pengembangan).

5. Penutup (penugasan)

Memberikan penugasan/PR kepada peserta didik agar peserta didik juga belajar di rumah. Waktu pemberian PR diakhir proses pembelajaran yang barusan diajarkan.

Mencermati Model Pembelajaran Missouri Mathematics Project tersebut diatas dapat disebutkan beberapa kelebihannya, antara lain:

1. Banyaknya materi yang bisa tersampaikan kepada siswa karena tidak terlalu memakan banyak waktu, artinya penggunaan waktu dapat diatur relatif ketat.

2. Banyak latihan sehingga siswa mudah terampil dengan beragam soal.

Adapun kekurangan atau kelemahannya adalah:

1. Kurang menempatkan peserta didik pada posisi yang aktif.

2. Mungkin peserta didik cepat bosan karena lebih banyak mendengarkan. 
Menurut Suprijono, model pengajaran langsung adalah model pembelajaran yang pendekatannya menfokuskan pada suatu pendekatan mengajar yang dapat membantu siswa mempelajari keterampilan dasar dan memperoleh informasi yang dapat diajarkan selangkah demi selangkah. Pengajaran langsung selain dikenal dengan sebutan active teaching juga dinamakan whole - class teaching yang mengaju pada gaya mengajar dimana guru terlibat aktif dalam mengusung isi pelajaran kepada peserta didik dan mengajarkannya secara langsung kepada seluruh kelas.

Mencermati Model Pengajaran Langsung maka dapat disebut kelebihan kelebihannya:

1. Relatif banyak materi bisa tersampaikan

2. Untuk hal - hal yang sifatnya prosedural, model ini akan relatif mudah di ikuti

3. Waktu pembelajaran yang mudah diatur

Adapun kekurangan - kekurangannya adalah sebagai berikut:

1. Jika terlalu dominan pada ceramah siswa akan cepat bosan

peserta didik cenderung menunggu jawaban secara mentah - mental dari materi yang disajikan oleh tenaga pengajar

Berdasarkan pertanyaan penelitian yang dikemukakan di atas, maka penelitian ini bertujuan :

1. Untuk mengetahui seberapa besar hasil belajar matematika siswa yang diajar dengan model pengajaran langsung di kelas VII SMP Negeri 5 Watampone.

2. Untuk mengetahui seberapa besar hasil belajar matematika siswa yang diajar dengan model Missouri Mathematics Project di kelas VII SMP Negeri 5 Watampone.

3. Untuk mengetahui apakah ada perbedaan hasil belajar matematika antara siswa yang diajar dengan menerapkan model pengajaran langsung dan siswa yang diajar dengan model pembelajaran Missouri Mathematics Project di kelas VII SMP Negeri 5 Watampone.

\section{METODE PENELITIAN}

Variabel dalam penelitian ada dua jenis, yakni variabel terikat dan variabel bebas. Variabel terikatnya adalah hasil belajar matematika, sedangkan variabel bebasnya adalah model pengajaran langsung dan model pembelajaran Missouri Mathematics Project. 
Penelitian ini merupakan penelitian eksperimen dengan desain penelitian yang digunakan adalah randomized control design. Model desainnya sebagai berikut:

Tabel 1. Desain Penelitian

\begin{tabular}{ccc}
\hline Kelompok & Variabel & Post test \\
\hline $\mathrm{R}_{1}$ & $\mathrm{X}_{1}$ & $\mathrm{O}$ \\
\hline $\mathrm{R}_{2}$ & $\mathrm{X}_{2}$ & $\mathrm{O}$ \\
\hline
\end{tabular}

\begin{tabular}{ll}
\multicolumn{2}{l}{ Keterangan: } \\
$\mathrm{R}_{1} \quad$ : Kelas eksperimen I \\
$\mathrm{R}_{2} \quad$ : Kelas eksperimen II \\
$\mathrm{X}_{1} \quad$ : Eksperimen pertama (model pembelajaran MMP) \\
$\mathrm{X}_{2} \quad$ : Eksperimen kedua (model pengajaran langsung) \\
$\mathrm{O} \quad$ : Tes Hasil Belajar
\end{tabular}

Penelitian ini akan dilaksanakan di Watampone Populasi dalam penelitian ini adalah siswa kelas VII SMP Negeri 5 Watampone yang terdiri atas 3 kelas yaitu VII $_{\mathrm{A}}$, $\mathrm{VII}_{\mathrm{B}}$, dan $\mathrm{VII}_{\mathrm{C}}$. Pengambilan sampel dalam penelitian ini untuk masing-masing kelompok digunakan teknik cluster random sampling dengan langkah-langkah:

1. Memilih 2 kelas yang sepadan dan memiliki karakteristik yang sama dari seluruh kelas VII SMP Negeri 5 Watampone.

2. Memilih salah satu dari 2 kelas secara random sebagai kelompok eksperimen.

3. Kelas yang tidak terpilih sebagai kelas eksperimen menjadi kelas kontrol.

4. Siswa yang terlibat dari kedua kelas tersebut merupakan sampel yang akan diselidiki dalam penelitian ini.

Teknik pengumpulan data dalam penelitian ini dilakukan dengan pemberian tes hasil belajar kepada masing-masing responden pada kedua kelompok (eksperimen dan kontrol). Pemberian tes dilakukan setelah kedua kelompok diberikan perlakuan (Treatment). Skor pada tes hasil belajar yang terkumpul itulah yang merupakan data hasil belajar yang selanjutnya akan dianalisis dalam penelitian ini.

Dalam pengumpulan data penulis menempuh beberapa tahap secara garis besar dibagi dalam dua tahap yaitu tahap persiapan dan tahap pelaksanaan penelitian .

1. Tahap Persiapan

a. Menyusun program pengajaran sesuai dengan kurikulum.

b. Menyusun instrumen yang disesuaikan dengan materi.

c. Melengkapi surat-surat izin penelitian. 
2. Tahap Pelaksanaan perlakuan (Treatment)

Pada tahap ini peneliti melaksanakan perlakuan (Treatment) dengan langkahlangkah sebagai berikut :

a. Menganalisis siswa, siswa dapat dianalisis berdasarkan karakteristik umum.

b. Memberikan informasi kepada siswa tentang materi yang akan diajarkan, tujuan pembelajaran dan pemberian motivasi agar siswa tertarik pada materi tersebut.

c. Memulai proses belajar mengajar. Kemudian melaksanakan prosedur dari model pengajaran langsung dan model Missouri Mathematics Project (MMP)tahap pertahap.

d. Mendata dan melihat perubahan apa yang terjadi pada siswa setelah diberi tindakan melalui penerapan model pembelajaran Missouri Mathematics Project (MMP).

e. Tahap evaluasi

Pada tahap ini peneliti memberikan tes untuk mengetahui hasil pembelajaran matematika.

Untuk memperoleh data tentang hasil belajar matematika siswa, digunakan satu perangkat alat instrument yaitu tes hasil belajar yang dibuat sendiri oleh peneliti dengan bimbingan dosen pembimbing/guru matematika di SMPN 5 Watampone.

Tes ini digunakan untuk mengukur tingkat penguasaan siswa terhadap materi setelah belajar dalam jangka waktu tertentu. Bentuk tes yang digunakan adalah bentuk essay. Namun sebelum tes hasil belajar itu dibuat, terlebih dahulu dibuatkan kisi - kisi agar masing - masing bagian dalam materi dapat terwakilkan secara proporsional dalam tes.

Teknik analisis data yang digunakan dalam penelitian ini adalah:

\section{Analisis Statistik Deskriptif}

Menurut Sugiyono (2009), statistik deskriptif adalah statistik yang digunakan untuk menganalisis data dengan cara mendeskripsikan atau menggambarkan data yang telah terkumpul sebagaimana adanya, tanpa bermaksud membuat kesimpulan yang berlaku umum. Dalam penelitian ini, analisis statistik deskriptif digunakan untuk mendeskripsikan hasil belajar matematika siswa pada setiap kelompok yang telah dipilih.

2. Analisis Statistik inferensial

Statistik inferensial adalah teknik statistik yang digunakan untuk menganalisis data sampel dan hasilnya diberlakukan untuk populasi. Teknik statistik ini dimaksudkan 
untuk menguji hipotesis penelitian. Untuk menguji hipotesis penelitian, dilakukan dengan tahapan uji normalitas dan uji homogenitas.

a. Uji Normalitas

Uji normalitas merupakan langkah awal dalam menganalisis data secara spesifik. Uji normalitas digunakan untuk mengetahui data berdistribusi normal atau tidak. Pada penelitian ini digunakan uji One Sample Kolmogorov-Smirnow dengan menggunakan taraf signifikan $5 \%$ atau 0,05 . Kriteria pengujian hipotesis adalah jika signifikansi lebih besar dari taraf signifikansi $\alpha=0,05$, maka secara statistik data berasal dari populasi yang berdistribusi normal.

b. Uji Homogenitas

Uji Homogenitas dilakukan untuk menyelidiki variansi kedua sampel sama atau tidak. Uji yang digunakan adalah uji Levene's test. Uji ini dilakukan sebagai prasyarat dalam analisis t-Test. Jika sampel tersebut memiliki variansi yang sama, maka keduanya dikatakan homogen. Pada uji levene's Test digunakan taraf signifikansi $5 \%$ atau 0,05 . Kriteria pengujian hipotesis adalah jika signifikansi lebih besar dari taraf signifikansi $\alpha=0,05$, maka secara statistik kedua variansi sama atau data homogen.

Untuk menguji hipotesis penelitian yang dirumuskan dan hipotesis kerja/statistik digunakan t-test untuk mengetahui ada atau tidaknya perbedaan rata - rata antara dua kelompok sampel yang tidak berhubungan.

Kriteria yang digunakan untuk menentukan kategori hasil belajar matematika siswa kelas VII SMP Negeri 5 Watampone pada pokok bahasan himpunan dalam penelitian ini adalah sesuai dengan Kriteria Ketuntasan Minimal (KKM) dari ketentuan sekolah yaitu $\geq 60$. Apabila rata-rata siswa mencapai nilai $60 \mathrm{ke}$ atas atau mencapai ketuntasan perorangan.

\section{HASIL PENELITIAN DAN PEMBAHASAN}

\section{A. Hasil Analisis Statistika Deskriptif}

1. Kreativitas Matematika Siswa Yang Diajar Dengan Model Pembelajaran MMP Dengan pendekatan Open Ended

Berdasarkan hasil analisis data deskriptif, berikut ini akan disajikan kreativitas matematika siswa pada kelas eksperimen I : 
Histogram: Jurnal Pendidikan Matematika, Volume 1 Nomor 2, September 2017, pp 76-90

Tabel 2. Rangkuman skor statistik kelas Eksperimen I.

\begin{tabular}{cc}
\hline Statistik & Nilai Statistik \\
\hline Ukuran sample & 33 \\
Mean & 73,06 \\
Standar Deviasi & 8,609 \\
Variansi & 74,121 \\
Skor terendah & 51 \\
Skor tertinggi & 94 \\
Skewness & $-0,085$ \\
\hline
\end{tabular}

(Sumber: Data Primer, Tahun: 2016)

Berdasarkan Tabel 2 dapat disimpulkan bahwa dari 33 orang siswa kelas $\mathrm{VII}_{\mathrm{D}}$ yang diajar dengan model pembelajaran MMP pada umumnya memiliki kreativitas matematika dengan skor rata-rata 73,06 dari skor ideal 120.

2. Kreativitas Matematika Siswa Yang Dajar Dengan Model Pengajaran Langsung Dengan Penekatan Open Ended

Berdasarkan hasil analisis data deskriptif pada lampiran $\mathrm{C}$, berikut ini akan disajikan kreativitas matematika siswa pada kelas eksperimen II :

Tabel 3. Rangkuman skor statistik kelas Eksperimen II.

\begin{tabular}{cc}
\hline Statistik & Nilai Statistik \\
\hline Ukuran sample & 35 \\
Mean & 76,63 \\
Standar Deviasi & 7,811 \\
Variansi & 61,005 \\
Skor terendah & 54 \\
Skor tertinggi & 90 \\
Skewness & $-0,471$
\end{tabular}

(Sumber: Data Primer, Tahun: 2016)

Berdasarkan Tabel 3 dapat disimpulkan bahwa dari 35 orang siswa kelas VII $_{\mathrm{E}}$ yang diajar dengan model pembelajaran langsung pada umumnya memiliki kreativitas matematika dengan skor rata-rata 76,63 dari skor ideal 120.

Pada data Tabel 2 dan Tabel 3 nilai skweness kedua model pembelajaran adalah negative yaitu MMP sebesar $-0,085$ dan Pengajaran Langsung sebesar -0,471. Nilai 
koefisien kemiringan (skweness) yang bernilai negative menandakan bahwa kurva condong ke kanan atau menceng ke kiri, dalam hal ini berarti bahwa frekuensi skor di atas rata-rata lebih besar daripada skor di bawah rata-rata pada kedua model pembelajaran tersebut. Hal ini, terlihat pada histogram berikut :

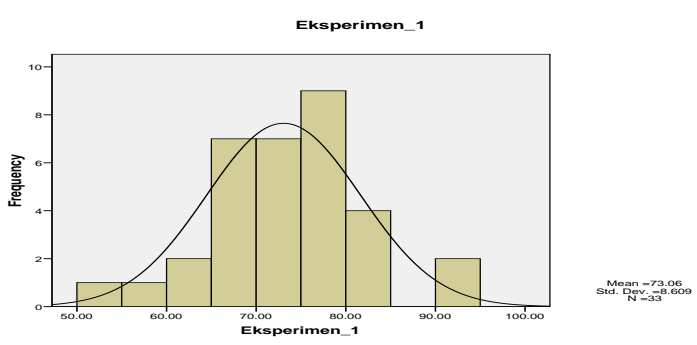

Gambar 1. Histogram Skor Kreativitas Siswa pada Kelas Eksperimen I.

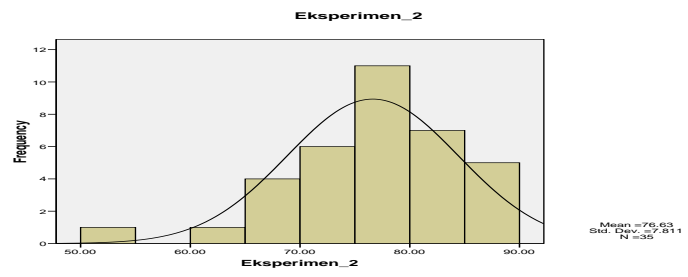

Gambar 2. Histogram Skor Kreativitas Siswa pada Kelas Eksperimen II.

\section{B. Hasil Analisis Statistik Inferensial}

Hasil analisis statistika inferensial dimaksudkan untuk menjawab hipotesis penelitian yang telah dirumuskan. Sebelum melakukan analisis statistika inferensial terlebih dahulu dilakukan uji asumsi yaitu uji normalitas dan uji homogenitas.

\section{a. Uji Normalitas}

Uji normalitas dilakukan terhadap nilai masing-masing kelompok dengan tujuan untuk mengetahui populasi data berdistribusi normal atau tidak. Seluruh perhitungannya dilakukan dengan menggunakan bantuan komputer dengan program Statistical Package for Social Sciense (SPSS) versi 18.0 dengan uji Kolmogrov-Smirnov Normality Test.

Hipotesis yang akan diuji sebagai berikut:

$H_{0} \quad$ : Populasi berdistribusi normal 
$H_{1} \quad$ : Populasi tidak berdistribusi normal

Kriteria pengujian : Menolak $H_{0}$ apabila nilai $p$-value $<\alpha$

Berdasarkan hasil analisis data dengan menggunakan analisis KolmogrovSmirnov Normality Test diperoleh hasil hitung untuk kelas eksperimen I nilai $p-$ value $>\alpha$ yaitu $0,200>\alpha$ dan kelas eksperimen II nilai $p$-value $>\alpha$ yaitu $0,200>\alpha$ (taraf signifikasi $\alpha=0,05)$. Sehingga dapat disimpulkan untuk menerima $H_{0}$ atau populasi berdistribusi normal. Jadi pengujian normalitas terpenuhi.

b. Uji Homogenitas

Berdasarkan hasil pengujian normalitas populasi, ternyata kedua kelompok eksperimen mempunyai data yang berdistribusi normal, maka dilanjutkan uji homogenitas. Pengujian homogenitas digunakan untuk mengetahui apakah data yang akan dikorelasikan itu memenuhi kekonstantaan varians (homogen), pengujian homogenitas dapat dihitung dengan menggunakan uji Levene's test for equality of variances.

Hipotesis yang akan diuji sebagai:

$H_{0} \quad$ : Populasi variansi homogen

$H_{1} \quad$ : Populasi variansi tidak homogen

Kriteria pengujian: Menolak $H_{0}$ apabila nilai $p$-value $<\alpha$

Berdasarkan hasil analisis data dengan menggunakan uji Levene's test for equality of variances diperoleh hasil hitung untuk nilai $p$-value $>\alpha$ yaitu 0,682 $>$ 0,05 , sehingga dapat disimpulkan untuk menerima $H_{0}$ yang berarti variansi kedua populasi adalah homogen. Jadi pengujian homogenitas terpenuhi. Pada keadaan seperti ini maka pengujian hipotesis dapat dilakukan.

c. Pengujian Hipotesis

Pengujian hipotesis dalam penelitian ini diuji dengan menggunakan uji-T, dimana sebelumnya diadakan pengujian persyaratan. Hipotesis yang dirumuskan:

$H_{0}$ : Tidak ada perbedaan kreativitas matematika siswa yang diajar antara pembelajaran model MMP dan model pengajaran langsung.

$H_{1}$ : Ada perbedaan kreativitas matematika siswa yang diajar antara pembelajaran model MMP dan model pengajaran langsung.

Kriteria pengujian hipotesis: Menolak $H_{0}$ apabila nilai $\frac{1}{2} p-$ value $<\alpha$

Berdasarkan tabel Independent Samples Test pada kolom sig.(2-tailed) diperoleh nilai sebesar 0,078 (jadi $\frac{1}{2} p-$ value $=0,0005$ ) yang lebih besar dari taraf signifikansi 
0,05 yang berarti bahwa tidak terdapat perbedaan kreativitas matematika siswa antara model pembelajaran MMP dan Pengajaran Langsung. Hal ini menunjukkan bahwa salah satu model pembelajaran lebih baik dari model pembelajaran lain, dengan demikian melalui hasil analisis dapat disimpulkan bahwa kreativitas matematika siswa yang diajar menggunakan model pembelajaran MMP dan menggunakan model pengajaran langsung adalah sama.

\section{Pembahasan}

Setelah dilakukan penelitian dan analisis data tidak ditemukan adanya perbedaan kreativitas siswa yang diajar dengan model pembelajaran MMP dan Pengajaran Langsung. Berdasarkan hasil penelitian yang dianalisis menggunakan statistika deskriptif memperlihatkan bahwa skor rata-rata kreativitas siswa yang diajarkan dengan model pembelajaran MMP tidak lebih baik dibandingkan dengan skor rata-rata kreativitas siswa yang diajarkan dengan model Pengajaran Langsung.

Berdasarkan hasil perhitungan statistika inferensial dengan menggunakan uji-T juga memperlihatkan tidak adanya perbedaan kreativitas siswa yang diajar dengan model pembelajaran MMP dan Pengajaran Langsung.

Berdasarkan hasil analisis deskriptif dan inferensial terlihat bahwa skor rata-rata kreativitas siswa yang diajar dengan model Pengajaran Langsung lebih tinggi dibandingkan dengan skor rata-rata kreativitas siswa yang diajar dengan model pembelajaran MMP, sehingga dapat disimpulkan bahwa pembelajaran matematika dengan model pembelajaran MMP tidak memberikan pengaruh terhadap kreativitas siswa. Struktur pembelajaran dan situasi kelas dalam proses pembelajaran yang berbeda antara kedua model tersebut tidak mempengaruhi kreativitas siswa.

Ditinjau dari keterlibatan siswa dalam proses belajar mengajar, siswa yang diajar menggunakan model pembelajaran MMP memang lebih banyak terlibat dalam kegiatan belajar mengajar daripada siswa yang diajar menggunakan model pengajaran langsung. Sedangkan siswa yang diajar menggunakan model pengajaran langsung cenderung pasif dan yang terlibat lebih sedikit, karena guru lebih banyak mendemonstrasikan pengetahuan atau keterampilan atau dengan kata lain pusat pembelajaran lebih banyak pada guru.

Dengan menggunakan model pembelajaran MMP tidak memberikan pengaruh terhadap kreativitas matematika siswa. Dengan penerapan model pembelajaran MMP tidak mempengaruhi proses pemecahan masalah dan membuat ide Siswa SMP Negeri 27 Makassar, terlihat pada pengisian angket kreativitas yang diberikan pada akhir pertemuan. Dalam model pembelajaran MMP siswa lebih aktif dibandingkan dengan 
model pengajaran langsung tapi bagi siswa yang kurang akan jauh tertinggal karena lebih banyak mendengarkan dan kurang berinteraksi dengan guru. Sedangkan dalam pengajaran langsung siswa lebih banyak berinteraksi dengan guru dalam proses penyampaian materi.

\section{KESIMPULAN DAN SARAN}

\section{A. Kesimpulan}

Berdasarkan hasil anaslis data yang mengacu pertanyaan penelitian, maka hasil penelitian dapat disimpulkan sebagai berikut:

1. Hasil belajar matematika siswa yang diajar dengan model pembelajaran MMP mempunyai skor rata-rata sebesar 74,37 yang telah mencapai nilai KKM dengan standar deviasi 12,14 dan persentase ketuntasan 88,89\%.

2. Hasil belajar matematika siswa yang diajar dengan model pengajaran langsung mempunyai skor rata-rata sebesar 61,81 yang telah mencapai nilai KKM dengan standar deviasi 13,18 dan persentase ketuntasan 61,54\%.

3. Ada perbedaan hasil belajar matematika siswa yang diajar dengan model pembelajaran MMP dan Pengajaran Langsung.

4. Hasil belajar matematika siswa kelas VII SMPN 5 Watampone yang diajar dengan model pembelajaran MMP lebih baik dari hasil belajar matematika siswa yang diajar dengan menggunakan model pengajaran langsung.

\section{B. Saran}

Mengacu kepada deskripsi pembahasan hasil penelitian dan kesimpulan di atas maka berikut akan dikemukakan beberapa saran antara lain:

1. Kepada Bapak/ibu guru dalam mengajarkan materi pembelajaran, sebaiknya guru tidak hanya berfokus pada satu model pembelajaran saja, melainkan menggunakan beberapa model, sehingga siswa tidak merasa bosan dalam menerima pelajaran yang diberikan.

2. Diharapkan kepada guru terutama guru bidang studi matematika agar mempertimbangkan model pembelajaran MMP dan model pengajaran langsung.

3. Disarankan kepada peneliti lain yang berminat untuk mengadakan penelitian lebih lanjut pada model pembelajaran yang berbeda agar diperoleh wawasan yang lebih luas dalam usaha peningkatan hasil belajar. 


\section{DAFTAR PUSTAKA}

Al Krismanto. (2003). Beberapa Teknik, Model, dan Strategi dalam Pembelajaran Matematika. http://matemarso.files.wordpress.com/2008/04/strategipembelajaran-matematika.pdf. ( 9 Oktober 2011)

Anniza, Nur. (2011). Meningkatkan Hasil Belajar Matematika Melalui Model Pembelajaran Missouri Mathematic Project (MMP) Pada Siswa Kelas X Smk Negeri 2 Jeneponto.Makassar: Universitas Muhammadiyah Makassar.

Anwar, Desi. (2003). Kamus Lengkap Bahasa Indonesia. Cet I. Surabaya: Amelia Surabaya.

Hamalik, oemar. (2001). Kurikulum dan Pembelajaran. Bumi Aksara: Bandung.

Hariani. Peningkatan Hasil Belajar Matematika Siswa Kelas II Mesin Otomotif SMK YP-PGRI Makassar melalui Model Pembelajaran Langsung dengan Pendekatan Kontekstual. Makassar: FMIPA UNM, 2007.

Nuharini, Dewi. (2008). Matematika Konsep Dan Aplikasinya. Jakarta: Pusat Perbukuan, Departemen Pendidikan Nasional.

Pasaribu, dkk. (1983). Proses Belajar Mengajar. Bandung: Tarsito.

Pujiati,Irma. (2008). Peningkatan Motivasi Dan Ketuntasan Belajar Matematika Melalui Pembelajaran Kooperatif Tipe Stad.

http://jurnal.ump.ac.id/_berkas/jurnal/22.pdf.diakses.Diakses 5 mei 2010.

Sardiman. (2004). Interaksi dan Motivasi belajar mengajar. Jakarta: Raja Grafindo Persada.

Slameto. (1995). Belajar dan Faktor-faktor yang mempengaruhinya. Jakarta: Rineka Cipta.

Soedjadi. (2000). Kiat pendidikan matematika di Indonesia. Jakarta: Direktorat jenderal Pendidikan Tinggi, departemen Pendidikan Nasional.

Sugiyono. (2009). Metode Penelitian Pendidikan.(Pendekatan Kuantitatif, kualitatif, dan $R \& D)$. cet.VIII. Bandung: Alfabeta. 